\title{
Altitudinal Diversity of Forensic Blowflies (Diptera: Calliphoridae) of Western Ghats (Maharashtra)
}

\author{
Divya Jadav and Sathe TV* \\ Department of Zoology, Shivaji University, Kolhapur, India
}

\begin{abstract}
Western Ghats is one of the 18 hot spots of the world for biodiversity conservation and protection. Increasing human activities and tourism in forestry and changing life style of humans lead more difficult to solve criminal cases Blow flies (Diptera: Calliphoridae) are important components of decomposition process of wild and human bodies in forest ecosystems. Biotic and abiotic factors of environment have direct impact on population dynamics of flora and fauna of forensic importance. The blow flies use carrion as a resource for propagation of their own progeny. Therefore, altitudinal diversity of forensic blow flies in Western Ghats has been reported. A total of 19 species of blow flies belonging to the genera Chrysomya, Lucilia and Calliphora have been reported. The genus Lucilia and Chrysomya were abundant at low altitude than higher altitudes of Western Ghats. In general, blow fly diversity decreased with increase of altitudes and qualitative faunal diversity of blow flies were different at different study spots. The outcome of faunal turn over analysis clearly indicated that assemblage at $545 \mathrm{~m}$ and $585 \mathrm{~m}$ share almost $71.42 \%$ of their fauna in common. Also elevation of $900 \mathrm{~m}$ shares $70.70 \%$ of its assemblage with $585 \mathrm{~m}$. Similarly, assemblage at $42 \mathrm{~m}$ and $22 \mathrm{~m}$ share about $40 \%$ of their fauna in common. The life cycle under laboratory $\left(27 \pm 1{ }^{\circ} \mathrm{C}\right.$, $70-80 \%, 12$ hours photo period) ranged from $9-11$ days in the species, C. erythrocephala and $L$. sericata.
\end{abstract}

Keywords: Altitudinal diversity; forensic blowflies; Developmental time; Western Ghats Maharashtra; India

\section{Introduction}

Blow flies (Diptera: Calliphoridae) are commonly called green bottles and blue bottles. The blue bottles Calliphora occur commonly around houses in search of breeding material and food and attracted to meat, carrion, feacal matter and dead animals for egg laying and to cheese for food. The genus Chrysomya includes green bottles of large size and metallic green colour and cause myiasis in human and other animals in India. This genus is reported from India, Africa, Philippines, Celebes and New Guinea. Lucilia species are also known as green bottles and are metallic, shining green but smaller and less bristly than Calliphora. The larvae of Lucilia infect wounds and body cavities in man and some attacks sheep in India. Western Ghats is one of 18 hot spots of the world for conservation and protection of biodiversity. Biotic and abiotic factor have direct impact on population dynamics of flora and fauna. Extension tourism in forestry and changing life style of humans lead criminal cases. Therefore, altitudinal diversity of blow flies in Western Ghats will add great relevance in protecting wild and human life and the data will be helpful to forensic science. Review of literature indicates that forensic insects have been studied with respect to diversity, biology, development and utility in forensic science by Senior-white [1], James [2], Smith [3], Greenberg [4], Kurahashi and Thapa [5], Smith and Wall [6], Anderson [7], Dadour et al. [8], Kurahashi [9], Tachibana and Numata [10], Bharti and Singh [11], Grassberger et al. [12], Pitts and Wall [13], Clark et al. [14] Bharti $[15,16]$ Bharti and Kurahashi [17], Higley and Haskel [18], Shiravi et al. [19], Sathe and Jadhav [20,21], Sathe et al., [22] Vasconcelos et al.[23], Ghodake et al. [24] etc.

\section{Materials and Methods}

Collection of blow flies were made during the years 2012-13 from Kolhapur city, Radhanagari, Gaganbawada, Vaibhavwadi, Kankawali and Sindhudurg covering most of the altitudal and road side spots. The blow flies were collected with the help of sweeping net from the carcasses. The carcasses of dogs, cats and cows were used in the present study. Collections were made weekly. After recording morphological features and identification, the blow flies were released in the environment from which they were collected. A fresh piece of goat meat $4 \times 4 \mathrm{~cm}$ was placed in mesh cage $25 \times 25 \times 25 \mathrm{~cm}$ and cages were kept road sides at each study spot in the areas where there was no interference of scavengers and carnivores and collection of blow flies was made after 30 minutes of placement of cage in the field and diversity was recorded (Table 1). Geographical and climatic data of study spots have been noted in the Table 3. Developmental studies were conducted at laboratory conditions $\left(27 \pm 1^{\circ} \mathrm{C}, 70-80 \%, 12 \mathrm{hr}\right.$ photo period) in 10 groups of plastic bottles. The bottles were ventilated with numerous holes. Life cycles of $C$. erythrocephala and $L$. sericata were determined by recording the average time in days, for different stages for each species. Recording the time required for egg hatching, larval stage developments and pupation and total time for egg to imago was performed every six hr intervals. The rate of development was measured for each life stage.

\section{Results}

Results are recorded in the Tables 1-3 and Figures 1-4. In all, 19 species of blow flies have been reported from the selected spots of Western Ghats (Maharashtra) (Table 1) belonging to the genera Chrysomya, Lucilia and Calliphora. The genus Chrysomya was represented by 6 species namely Chrysomya megacephala, C.indica,

*Corresponding author: Sathe TV, Professor in Entomology, Department of Zoology, Shivaji University, Kolhapur-416 004, India, Tel: +917276309148; E-mail: profdrtvsathe@rediffmail.com

Received August 16, 2014; Accepted October 30, 2014; Published Novembe 05, 2014

Citation: Jadav D, Sathe TV (2014) Altitudinal Diversity of Forensic Blowflies (Diptera: Calliphoridae) of Western Ghats (Maharashtra). J Forensic Res 5: 251. doi:10.4172/2157-7145.1000251

Copyright: ( 2014 Jadav D, et al. This is an open-access article distributed under the terms of the Creative Commons Attribution License, which permits unrestricted use, distribution, and reproduction in any medium, provided the original author and source are credited. 
Citation: Jadav D, Sathe TV (2014) Altitudinal Diversity of Forensic Blowflies (Diptera: Calliphoridae) of Western Ghats (Maharashtra). J Forensic Res 5: 251. doi:10.4172/2157-7145.1000251

Page 2 of 4

\begin{tabular}{|c|c|c|}
\hline Sr. No. & Place & Species recorded \\
\hline 1. & Kolhapur & $\begin{array}{l}\text { Chrysomyamegacephala (Fab.) } \\
\text { Chrysomyarufifacies (Macquart) } \\
\text { Chrysomyaindica } \\
\text { Luciliaampullacea Villeneuve } \\
\text { Luciliapapuensis Macquart } \\
\text { Luciliaporphyrina (Walker) } \\
\text { Calliphoraerythrocephala (Meigen) }\end{array}$ \\
\hline 2. & Radhanagari & $\begin{array}{l}\text { Chrysomyamegacephala (Fab.) } \\
\text { Chrysomyarufifacies (Macquart) } \\
\text { Chrysomyanigricpes (Wied.) } \\
\text { Luciliaampullacea Villeneuve } \\
\text { Luciliapapuensis Macquart } \\
\text { Luciliasericata (Meigen) } \\
\text { Calliphoraerythrocephala (Meigen) }\end{array}$ \\
\hline 3. & Gaganbawda & $\begin{array}{l}\text { Chrysomyamegacephala (Fab.) } \\
\text { Chrysomyarufifacius (Macquart) } \\
\text { Chrysomyanigripes (Wied.) } \\
\text { Luciliaampullacea Villeneuve } \\
\text { Luciliaillustris (Meigen) } \\
\text { Calliphorapattoni Aubertin }\end{array}$ \\
\hline 4. & Vaibhavwadi & $\begin{array}{l}\text { Chrysomyamegacephala (Fab.) } \\
\text { Chrysomyanigripes (Wied.) } \\
\text { Chrysomyamarginalis (Meigen) } \\
\text { Luciliacuprina (Wiedmann) } \\
\text { Luciliaampullacea Villeneuve } \\
\text { Calliphorapattoni Aubertin } \\
\text { Calliphorabazini }\end{array}$ \\
\hline 5. & Kankawali & $\begin{array}{l}\text { Chrysomyamegacephala (Fab.) } \\
\text { Chrysomyanigripes (Wied.) } \\
\text { Chrysomyamarginalis (Meigen) } \\
\text { Luciliacuprina (Wiedmann) } \\
\text { Luciliaillustris (Meigen) } \\
\text { Calliphorapattoni Aubertin } \\
\text { Calliphorabazini }\end{array}$ \\
\hline 6. & Sindhudurg & $\begin{array}{l}\text { Chrysomyamegacephala (Fab.) } \\
\text { Chrysomyanigripes (Wied.) } \\
\text { Chrysomyamarginalis (Wied.) } \\
\text { Chrysomyarufifacies (Macquart) } \\
\text { Chrysomyabezziana Villenovuve } \\
\text { Luciliaporphyrina (Walker) } \\
\text { Luciliaampullacea Villenovuve } \\
\text { Luciliasericata (Meigen) } \\
\text { Luciliapapuensis Macquart } \\
\text { Luciliacuprina (Wiedmann) } \\
\text { Luciliaandrewsi Senior-white et al. } \\
\text { Calliphoravomiforia (Linn.) } \\
\text { Calliphoraerythrocephala (Meigen) }\end{array}$ \\
\hline
\end{tabular}

Table 1: Calliphorids recorded from Western Ghats (Maharashtra).

\begin{tabular}{|l|c|c|c|c|}
\hline Place & Dog & Cat & Cow & Goat meat \\
\hline Kolhapur & 442 & 172 & 521 & 20 \\
\hline Radhanagari & 220 & 142 & 410 & 18 \\
\hline Gaganbawda & 115 & 75 & 147 & 12 \\
\hline Vaibhavwadi & 190 & 111 & 350 & 15 \\
\hline Kankawali & 222 & 113 & 371 & 18 \\
\hline Sindhudurg & 510 & 214 & 559 & 24 \\
\hline
\end{tabular}

Table 2: Blow flies collected on different carcasses in Western Ghats.

C.bazziana, C.rufifacies, C.nigripes and C. marginalis and the genus Lucilia by nine species, Lucilia sericata, L. cuprina, L. vicina, $L$. papuensis, L. ampullacea, L. illustris, L. porphyrina, L. andrewsi and L. bazini while, the genus Calliphora represented by only four species viz, Calliphora vicina, C.erythrocephala, C.vomitono and C. bazini. In Kolhapur city, the genera Lucilia, Chrysomya and calliphora were common with a total of seven species. Gaganbawda, the highest altitude spot showed Calliphora, Chrysomya and Lucilia genera with 1,3 and 2 species respectively. While the Sindhudurg, attitudinally lowest spot showed 13 species of blow flies belonging to the genera Chysomya,
Lucilia and Calliphora with 5, 6 and 2 species respectively (Table 1). The results indicated that the blow flies population was increased during the monsoon season than the winter and summer season and diversity of blow flies was found decreased with increase in altitude in the Western Ghats. It was noted that in almost every spot blowflies gathered on meat piece within half an hour expect Chrysomya which appeared 3 hours. The number of attracted blowflies was decreased with increase of altitude (Table 2). The blowflies were also found increased in number on goat meat after 30 minutes of exposure. In general, qualitative and quantitative diversity of blowflies were more in monsoon than winter and summer. The outcome of faunal turn over analysis clearly indicated that assemblage at $545 \mathrm{~m}$ and $585 \mathrm{~m}$ share almost $71.42 \%$ of their fauna in common. Also elevation of $900 \mathrm{~m}$ shares $70.70 \%$ of its assemblage with $585 \mathrm{~m}$. Similarly, assemblage at 42 $\mathrm{m}$ and $22 \mathrm{~m}$ share about $40 \%$ of their fauna in common.

Life cycle duration of C. erythrocephala and L. sericata from egg to adult indicated that they completed their life cycle on different carcasses (dog, cat, cow) within the range of 9 days to 11 days at 27 $\pm 1^{\circ} \mathrm{C}, 70-80 \%$ and $12 \mathrm{hr}$ photoperiod in the laboratory. There was not much difference in developmental life stages duration in both the species even on different carcasses (Table 4).

The life cycle of blow flies included four distinct stages viz, egg,

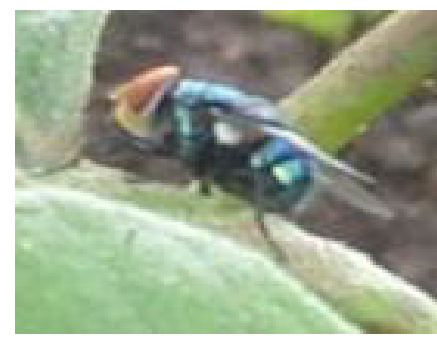

Figure 1: Calliphora sp.

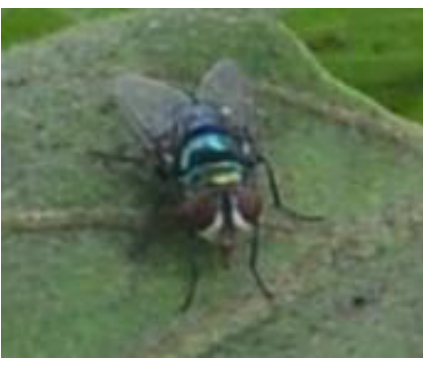

Figure 2: Calliphora $s p$.

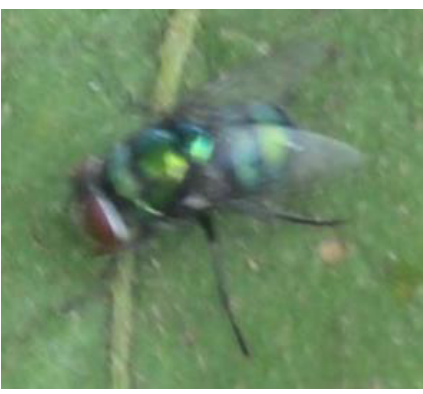

Figure 3: Chrysomya sp. 


\begin{tabular}{|c|c|c|c|c|c|c|c|}
\hline Sr No. & Place & Altitude (m) & Latitude $\left({ }^{\circ} \mathrm{N}\right)$ & Longitude $\left({ }^{\circ} \mathrm{E}\right)$ & Temperature $\left({ }^{\circ} \mathrm{C}\right)$ & Humidity (\%) & Rainfall (mm) \\
\hline 1. & Kolhapur & 545.6 & 16.42 & 74.16 & $10-40$ & $65-87$ & $1000-1025$ \\
\hline 2. & Radhanagari & 585.0 & 16.41 & 73.99 & $10-38$ & $67-90$ & 2500 \\
\hline 3. & Gaganbawda & 900 & 16.545 & 73.83 & $10-32$ & $64-94$ & $5000-6000$ \\
\hline 4. & Vaibhavwadi & 80 & 16.496 & 73.745 & $10-28$ & $64-97$ & 3240 \\
\hline 5. & Kankawali & 42 & 16.285 & 73.684 & $17-29$ & $59-92$ & 3200 \\
\hline 6. & Sindhudurg & 22 & 16.04 & 73.46 & $16.3-33.7$ & $65-95$ & 3300 \\
\hline
\end{tabular}

Table 3: Geographical and climatic conditions of study spots.

\begin{tabular}{|c|c|c|c|}
\hline \multirow{2}{*}{ Sr. No } & \multirow{2}{*}{ Carcass } & \multicolumn{2}{|c|}{ Developmental duration in days } \\
\cline { 3 - 4 } & & C. erythrocephala & L. sericata \\
\hline 1 & Dog & 9.00 & 9.5 \\
\hline 2 & Cat & 10.00 & 11.00 \\
\hline 3 & Cow & 9.5 & 10.00 \\
\hline
\end{tabular}

Table 4: Development of blow flies on different carcasses.

NO.OF SPECIES

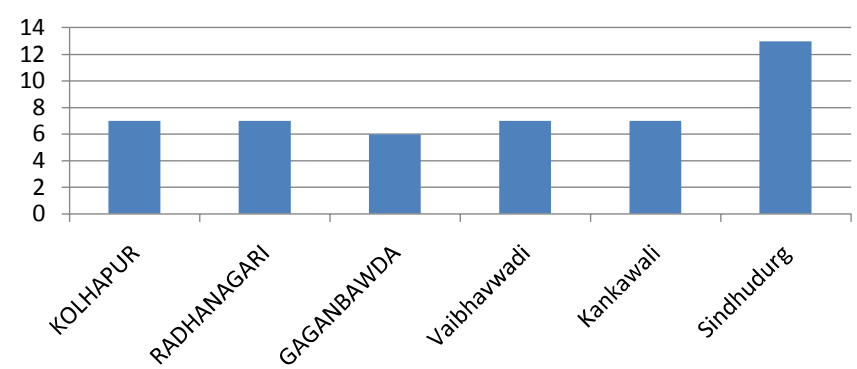

Figure 4: Abundance of blowflies in Western Ghats.

larva, pupa and imago. In the maggot stage 3 instars were noted. The flies deposited their eggs directly on carcasses. The eggs were elongated, the larvae were whitish opaque, legless and tapered towards anterior side and broader towards posterior side and were further characterized by number of respiratory slits at posterior end. The third instar was lasted longer than others on carcasses and found feeding on host tissues. The pupal duration was about half the length of the total development.

\section{Discussion}

According to Stevens and Walls [7,25-27] different species of Calliphorids have adapted to different feeding habits over the years for their survival and broadly divided as saprophages, facultative parasites like Chrysomya megacephala and Lucilia sericata and obligate parasites causing myiasis in man and other animals like Chrysomya bezziana. They were also adapted to various ecological niches. Bharati [4] studied altitudinal diversity of forensically important blow flies from Himalaya on decaying carcasses. A total of 14 species belonging to the genera Calliphora, Chrysomya and Lucilia have been reported. Out of 14 species, 6 were from the genus Chrysomya, 2 from the genus Calliphora while 6 were from the genus Lucilia. Bharti [4] further reported that at an elevation of $350 \mathrm{~m}$ (Shivalik range of Himalaya), a total of five species namely Chrysomya megacephala, Chrysomya rufifacies, Lucilia porphyrina, Lucilia papuensis and Lucilia ampullacea were present on the carcass. C. megacephala and L. papuensis were the most abundant species at this elevation. At $970 \mathrm{~m}$ also 5 species have been recorded $(C$. megacephala, C. rufifacies, C. nigripes, L. illustris and L. ampullacea). These species were found feeding and egg laying on the carcass. At this elevation, the fresh and bloating stages of decomposition of carcass were dominated by all 3 species of Chrysomya while, during the decay stage $C$. nigripes was most abundant. She reported maximum diversity of blow flies at an elevation of $2057 \mathrm{~m}$. A total of 8 species of blow flies were collected from cow carcass. Here C. megacephala and L. sericata were most abundant. Additional species occurred at this elevation were C. albiceps, C. pinguis, C. villeneuvi, L. sericata and L. cuprina and also Calliphora vicina. However, at an elevation of $2511 \mathrm{~m}$ only 3 species namely, C. villeneuvi and Calliphora vicina and Calliphora vomitoria were present. With increase in altitude there was a marked decrease in faunal diversity. In the present study, in Western Ghats (Maharashtra), maximum 13 species of blow flies were recorded from attitudinally lowest spot, Sindhudurg while, only six species have been reported from attitudinally highest spot, Gaganbawda. However, qualitative faunal diversity was different at different spots. The reason for maximum diversity of blow flies at Sindhudurg may be due to availability of more diverse host carcasses since it is a sea coastal spot.

Vasconcellos et al. [23] provided first check-list of forensically important dipteran species in a rainforest environment in North eastern Brazil, a region exposed to high rates of homicides. They used a decomposing pig, Sus scrofa L. (Artiodacetyla : Suidae), carcass as a model and adult flies were collected immediately after death and in the early stages of carcass decomposition. To confirm actual colonization of the carcass, insects that completed their larval development on the resource were also collected and reared until adult stage. They noted 28 species of seven families of order Diptera with necrophagus habits within few minutes after death. Out of 28 species, 11 have completed their larval development on carcass. The majority of individuals emerged from larvae collected at the dry stage of decomposition. Hemilucilia segmentaria Fab. (Calliphoridae), H. semidiaphana (Rondani) and Ophyra chalcoguster (Wied.) (Muscidae) were the dominant species among the colonizers. In the present study, carcasses of dog, cat and cow and goat meat were used. The dominant species found in the western Ghats was Chrysomya megacephala. However, the genus Lucilia represented maximum 6 species in the region with altitudinal specificity. At an elevation of $22 \mathrm{~m}$ Sindhudurg represented 6 species of Lucilia and 5 species of Chysomya.

Vasconcelos et al. [23] reported in total, 153 insects from 14 families in the first 3 hours after the death. This included species of Phoridae $24.2 \%$, Sarophagidae $18.3 \%$, Piophilidae $10.5 \%$, Calliphoridae $10.5 \%$, Fanniidae $8.5 \%$, Chloropidae 6.5\%, Muscidae $4.6 \%$ and Dixidae $4.6 \%$ while other families were in smaller proportions. The present study was pinpointed for the single family Calliphoridae. However, reporting other families from this region will be of great interest in future.

Determination of post mortem interval (PMI) or the time between death and the discovery of the corpse is the most important application of forensic entomology. Flies belong to the families Calliphoridae (blow flies) and Sarcophagidae (flesh flies) are often the first insects to arrive on a corpse where their larvae feed and breed effectively $[2,18]$. Developmental rates of flies are frequently used to estimate $\mathrm{PMI}$ in homicide investigations in the first few weeks after death. The development of immature insects is climate or temperature dependent. Therefore, PMI is normally calculated by the accumulated degree day/ hour model. 
According to Shiravi et al. [19] the developmental rates in $C$. albiceps and $L$. sericata were highly different in terms of accumulation of degree days required than that of the flesh fly Sarcophaga sp. They reported that the speed of development in the flesh fly was slower that blowflies. At $28^{\circ} \mathrm{C}$ the total developmental time from egg to adult was 13-19 days in Sarcophaga sp. While, in the present study the development was completed within the range of 9 to 11 days in both the species C. erythrocephala and L. sericata.

According to Hall and Doisy [26] the amount of time after death affected the structure of the assemblage of insects attracted to a carcass; a feature that will have direct implications on the accuracy of the biological information available to the forensic entomologist. Forest ecosystems are characterized by predator prey relations, parasitism, mutualism, symbiotism, etc. Therefore, forensic insects are supposed to be the indicators of ecologically varying regions and types of forests. The present work will add great relevance.

The speed of development in the flesh fly was also reported slower than blow flies [22]. Therefore, temperature requirements of some common forensically important blow and flesh flies (Diptera) under laboratory conditions have been studied by several workers $[1,12,19]$. They reported that rates of development decreased step by step as the flies grew from egg to larvae and then to adult stage. However, this rate was bigger for blow flies C. albiceps and L. sericata in comparison with the fleshy fly Sarcophaga sp. According to Gallagher et al. [27] the development of fly larvae is temperature dependant and in higher temperature, the rate of development increases and duration of development becomes shortened. The variation of developmental times between different populations emphasizes on specific characterization of regional developmental times and survival in the region. The present work was carried out at various altitude and climatic conditions. Therefore, the present data will be very useful for ecologists, environmentalist and in forensic science.

The development of blow flies is related with natural and synthetic diet, humidity and competition between larvae [14]. It has been noted that beef liver that are often used in laboratory rearing of flies produce offensive odours and contamination. The presence of toxins in decomposing tissues from natural diets has also been demonstrated affecting the developmental rate of blow flies [14]. On the liver of pigs and cows, the larvae of flies develop very fastly with larger adult size than tissues. An artificial diet, powdered milk caused a lower duration of larval stages in comparison with the animal liver [10]. Similarly, overcrowding of larvae also decreased the growth rate of blow flies leading to wrong conclusions [6]. Therefore, biology fecundity, intrinsic rate of increase of blow flies plays an important role in forensic cases. The present work will add great relevance in forensic science and environmental science for wild life protection and conservation.

\section{Acknowledgement}

Authors are thankful to Shivaji University, Kolhapur and Department of Environment and Forestry, Maharashtra for providing facilities.

\section{References}

1. Senior-white R, Aubertin D, Smart J (1940) The fauna of British-India including the reminder of the oriental region. Diptera Vol. II, Family Calliphoridae. Today and Tomorrow Publishers, New Delhi, India.

2. James MT (1947) The flies that cause myiasis in man. USDA Misc. 631: 175.

3. Smith KG (1986) A manual of forensic entomology. British Museum (National History), Cornell University Press, London.

4. Greenberg B (1991) Flies as forensic indicators. J Med Entomol 28: 565-577.
5. Kurahashi H, Thapa VK (1994) Notes on the NepalesCalliphorid flies (Insecta:Diptera). Jpn J Sanit Zool 45: 179-252.

6. Smith KE, Wall R(1997) Asymmetric copititionnetween larvae of the blow flies Calliphoravicina and Luciliasericata in carrion. Ecol Entomol 22: 468-474.

7. Anderson G (2001) Insect succession on carrion and its relationship to determining time of death. In: Byrd JH, Castner JL (Eds.): Forensic Entomology. The utility of Arthropods in legal Investigations CRC press, Boca Raton 143-177.

8. Dadour IR, Cook DF, Fissioli JN, Bailey WJ (2001) Forensic entomology: application, education and research in Western Australia. Forensic Scilnt 120: 48-52.

9. Kurahashi $\mathrm{H}$ (2001) The blow flies recorded from SriLanka with description of two new species (Diptera: Calliphoridae). Jpn J Syst Ent 7: 241-254

10. Tachibana SI, Numata H (2001) An artificial diet for blow fly larvae, Luciliasericata (Meigen) (Diptera: Calliphoridae). Appl Entomol Zool 36: 521 523.

11. Bharti M, Singh $D$ (2003) Insect faunal succession on decaying rabbit carcasses in Punjab, India. J Forensic Sci 48: 1133-1143.

12. Grassberger M, Friedrich E, Reiter C (2003) The blowfly Chrysomyaalbiceps (Wiedemann) (Diptera: Calliphoridae) as a new forensic indicator in Centra Europe. Int J Legal Med 117: 75-81.

13. Pitts K M, Wall R (2004) Adult mortality and oviposition rates in field and captive populations of the blow fly Luciliasericata. Ecol Entomol 29: 727-734.

14. Clark K, Evans L, Wall R (2006) Growth rates of the blowfly, Luciliasericata, on different body tissues. Forensic Scilnt 156: 145-149.

15. Bharti M (2009) Studies on life cycles of forensically important flies Calliphoravicina and Muscadomesticanebulo at varying temperatures. J Entomol Res 33: 273-275.

16. Bharti M (2012) Altitudinal diversity of forensically important blow flies collected from decaying carcasses in Himalaya. The Open Forensic Science Journal 5 : $1-3$.

17. Bharti M, Kurahashi H (2010) LuciliacalvicepsBezzi, new record from India (Diptera: Calliphoridae) with a revised key to Indian species. Halteres 1: 29-30.

18. Higley LG, Haskel NH (2010) Insect development and forensic entomology. In: Byrd JH, Castner JL (Eds). Forensic Entomology, the utility of arthropods in legal inventions. 2nd ed, Boca Raton CRC press LCC 389-405.

19. Shiravi A, Mostafavi R, Akbarzadeh K, Oshaghi M (2011) Temperature Requirements of Some Common Forensically Important Blow and Flesh Flies (Diptera) under Laboratory Conditions. Iran J Arthropod Borne Dis 5: 54-62.

20. Sathe TV, DivyaJadhav (2013) Sarcophagid fauna (Diptera:Sarcophagidae) of Kolhapur district. J Adv Zool 34: 85-87.

21. Sathe TV, DivyaJadhav(2014)Eclogy and control of eye flies, Siphunculina spp. (Chloropidae: Diptera). Int Nat J Pharma and biological Science 5: 214-220.

22. Sathe TV, AsawariSathe, Nishad TSathe (2013) Diversity of Dipterous forensic insects from Western Maharashtra, Indialnt J Pharma Bio Sci 4: 173-179.

23. Vasconcelos SD, Cruz TM, Salgado RL, Thyssen PJ (2013) Dipterans associated with a decomposing animal carcass in a rainforest fragment in Brazil: notes on the early arrival and colonization by necrophagous species. J Insect Sci 13: 145.

24. Ghodake D, Pawale D, SatheTV (2014) Forensic entomology solves the mysteries. Indian J Forensic Med and Toxicology 8: 12-15.

25. Hall RD, Doisy KE (1993) Length of time after death: effect on attraction and oviposition or larviposition of midsummer blow flies (Diptera: Calliphoridae) and flesh flies (Diptera: Sarcophagidae) of medicolegal importance in Missouri. Annent Soc Am 86: 589-593.

26. Al- Misned FAM, Amoudi, MA, Abou- Fannah SSM(2003) Development rate mortality and growth rate of immature Chrysomyaalbiceps (Wied.) (Diptera: Calliphoridae) at constant laboratory temperatures. J King Soud Univ Agric Sci15: 49-58.

27. Gallagher MB, Sandhu S,Kimsey R (2010) Variation in developmental time for geographically distinct populations of the common green bottle fly, Luciliasericata (Meign.) J For Sci 55(2): 438-442. 